\title{
The Early Breakthrough \\ of PSychoanalysis in Russia
}

owhere outside the centers of German-speaking Europe in Vienna and Zurich did psychoanalysis achieve such an early and broad breakthrough as in Russia. Over the course of a few years around 1910, deep psychology and Russian culture seem to have had an intense need for each other. Russia was working through its disappointment over the Revolution of 1905, and the new psychodynamic theory was evolving into its different variants. Under these conditions a remarkable cross-fertilization took place. By 1914, in fact, everything Sigmund Freud had written thus far had already been translated into Russian.

The first breakthrough year was 1909, when Freudian theory was described in detail in the two leading Russian psychiatric publications Zhurnal nevropatologii i psikhiatrii (Journal of Neuropathology and Psychiatry) and Sovremennaya psikhiatriya (Modern Psychiatry). The former featured an article by Dr. Nikolay Vyrubov entitled "Freud's Psychoanalytical Method and its Therapeutic Significance," in which he reported on his own experiences with the new therapy at the Kryukovo Sanatorium that he headed, while the latter carried a contribution in two sections by Dr. Osip Feltsman entitled "On Psychoanalysis and Psychotherapy" describing his own application of Freud's method. A report from Zurich in Sovremennaya psikhiatriya detailed a fascinating case of a female Russian-Jewish patient successfully treated by Carl Gustav Jung at Burghölzli. She was Sabina Spielrein, Jung's Freudian "experimental case," who at this time was herself studying to become an analyst and was involved in a complex romantic relationship with her former therapist. 

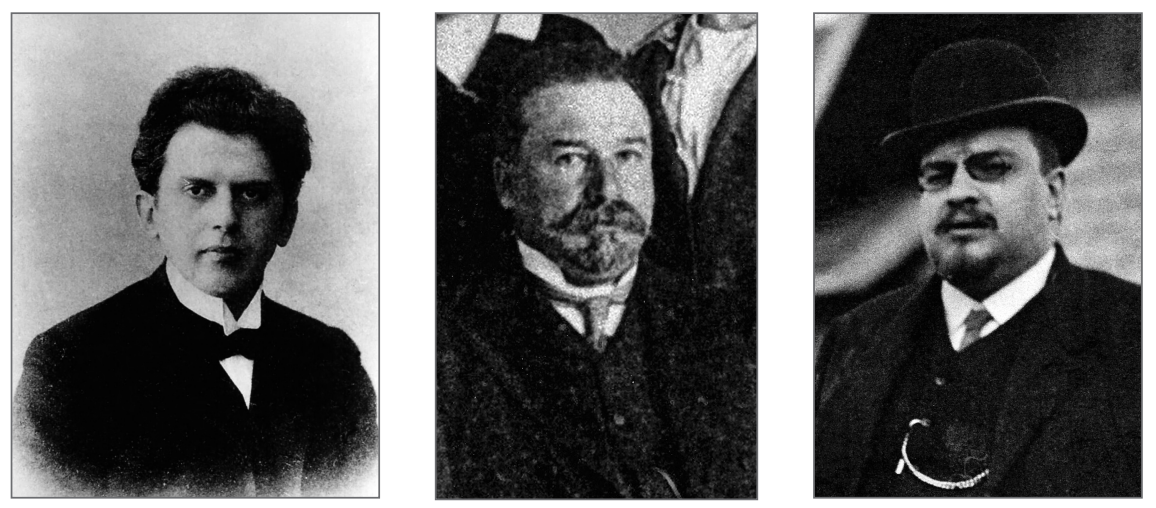

$\rho_{\text {ioneers of }} \rho_{\text {sychoanalysis: }}$

Osip Feltsman, 1912, Nikolay Vyrubov, 1912, and Nikolay Osipov, 1914.

Also in 1909, together with his colleagues Nikolay Osipov, Aleksandr Bernstein, and Yury Kannabikh, Dr. Vyrubov was planning to publish a bi-monthly journal, to be called Psikhoterapiya, which would be devoted exclusively to the new therapeutic ideas, especially psychoanalysis and the likewise much discussed "persuasive" method of Dr. Paul Dubois. Osipov, who was the driving force behind the project, had received his medical degree in Switzerland; almost all the leading Russian psychiatrists, in fact, had studied or practiced in German-speaking countries. In 1907 he had visited Jung at Burghölzli, and shortly thereafter he had worked with Jungian association tests as an assistant at the Moscow University Psychiatric Clinic. He also contributed many articles on psychoanalysis to the journals, particularly reviews and summaries of Freud's works, some of the originals of which he and Dr. Feltsman planned to publish in Russian in a special series.

Osipov was also the spirit behind the "little Fridays" at the University Clinic devoted to discussion of the new psychodynamic ideas, so named in contrast to the "big" Friday gatherings organized by the official Neuropathology and Psychiatry Society. At about this time the Society announced a contest for the best essay on the theme "The Psychoanalysis of Freud and Others in the Treatment of Functional Nervous Disorders." In December 1909, Osipov wrote to Freud personally to schedule a visit, which took place in 
June 1910. He made a very good impression on Freud, who sent an enthusiastic report on their meeting to his colleague Sándor Ferenczi in Budapest.

The first issue of Psikhoterapiya appeared in February 1910, six months before Freud's own journal Zentralblatt für Psychoanalyse, which was under the editorship of Alfred Adler and Wilhelm Stekel. Osipov was also on the editorial board of Zentralblatt, which guaranteed collaboration between the two publications. Another member of the board was Dr. Moisey Vulf (Moshe Woolf) from Odessa, who had introduced psychotherapy there in the local journal Terapevticheskoe obozrenie (Therapeutic Review) and had corresponded with Freud at about the same time as Osipov. It was not least through his efforts that Odessa soon followed Moscow to become the second center of deep psychology in Russia.

Psikhoterapiya now began publishing original articles, reviews and summaries, and before long it had developed a thoroughly psychoanalytical profile. Beginning in 1911, it also started to feature translations. Editor-in-chief Vyrubov and his wife translated many of Freud's shorter works. 1911-1912 also saw the translation into Russian of many of Freud's other writings. Vyrubov started his own series based on the journal translations, as did Vulf in Odessa. At about this time in Vienna both Vulf, who was visiting, and Sabina Spielrein, who arrived from Zurich, joined the Psychoanalytical Society. In November 1911, Spielrein presented there an excerpt from her article "Destruction as the Cause of Coming into Being," which inspired Freud's later theory of the death drive.

One could call 1912 the second and more definitive breakthrough year of psychoanalysis in Russia. In February 1911, after Osipov and some 130 professors and lecturers left the University to protest the government's repressive cultural policies, the "little Fridays" at the Moscow University Clinic were established as an independent forum. Attended by psychiatrists, pedagogues, and criminologists for discussions of the new psychotherapy, as early as March 1912 these open gatherings regularly attracted some 60 visitors. Aesthetic issues came up as well, for Kannabikh, Vyrubov, and Osipov, who organized the meetings, also had literary interests in common. Kannabikh wrote and even published 


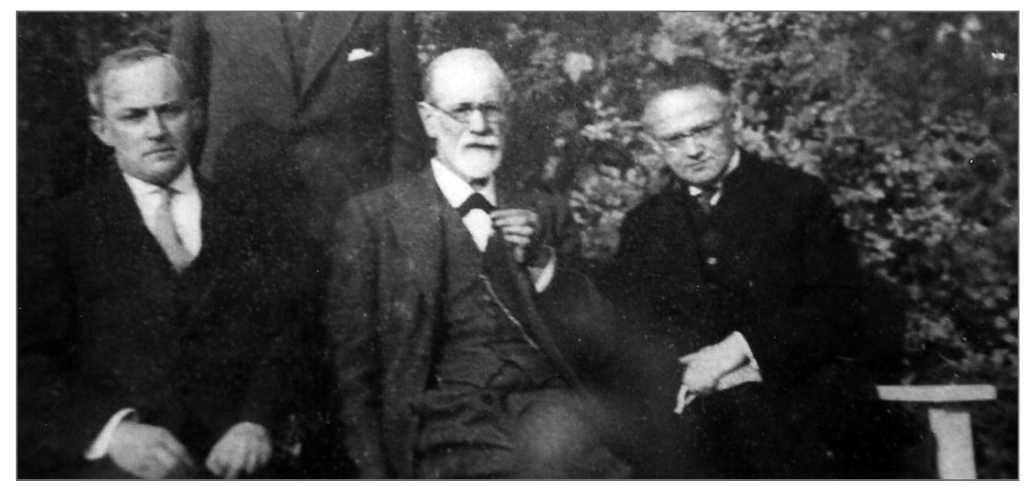

Sigmund Freud among Russians.

On his left, Max Eitingon, on the right, Moisey Vulf.

prose, while Osipov was working on a major Freudian study of Tolstoy, fragments of which appeared in Psikhoterapiya. In Osipov's interpretation, his works of fiction were primarily a stage in the writer's mental self-healing process.

The rapid spread of psychoanalysis in Russia is best understood in the light of the abortive Revolution of 1905 and the intelligentsia's psychic and moral crises in the wake of the increasingly repressive policies of the state. Freud's theory of neurosis proved valuable in coping with this situation. Many of the Russian doctors had a revolutionary past themselves, and, notably, many of them were Jews. Especially the cathartic and dynamic elements in Freud's method and personality theory seemed to speak directly to them. Yet at the same time they found it difficult to accept Freud's limitations and considered that his theories needed to be complemented in essential respects by the work of Alfred Adler, who attributed less significance to the instincts and took greater account of the role of social factors. Various objections to Freud's sexual dogma had been raised as early as 1909, for example, in Feltsman's introductory article in Sovremennaya psikhiatriya. Adler was himself a Social Democrat who had been deeply influenced by socially conscious Russian literature and the Russian intellectuals who went "to the people" in the 1870s. He had visited Russia together with his radical Russian Jewish wife, and through her had early on established contact with Mensheviks in Vienna, including Lev Trotsky. 


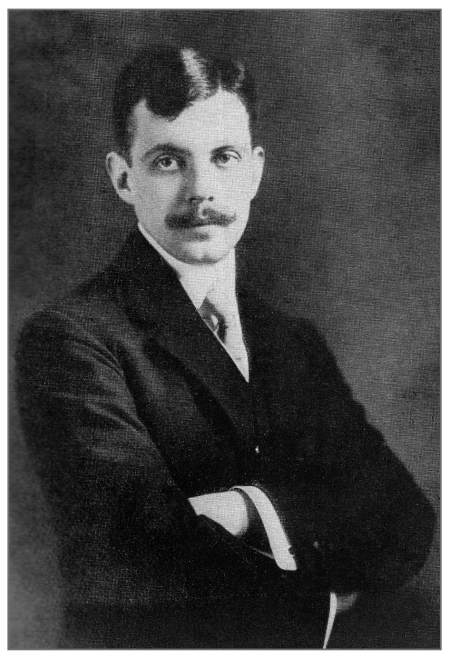

Sergey Pankeev, the Wolfman, circa 1910.

As Freudianism entered its second breakthrough phase in Russia, Psikhoterapiya began opening its pages to presentations of work Adler was doing on inferiority complexes and the aggressive will to power as the basis of neurosis. Vyrubov even joined Adler's newly founded society for "free psychoanalytical research," which was eventually renamed as the Society for Individual Psychology. When Freud broke with Zentralblatt in late 1912, the single remaining editor, Wilhelm Stekel, was actively supported by Adler in his effort to bind the journal even closer to Psikhoterapiya in Moscow through agreements providing for more extensive collaboration and exchanges of articles between the two publications. Adler and Stekel and a number of Adler's Russian and non-Russian followers from Odessa, Vienna, Budapest, Zurich, Basel, and Geneva soon joined the permanent staff of Psikhoterapiya. At the same time, the journal declared that it would continue to write "accurately" about Freud and would translate his works alongside those of Adler. The ideas of the two men were quite simply never considered to be as antagonistic in Russia as was the case in Vienna.

Adler's fascination with Russian literature inspired his twentyone year-old colleague Otto Kaus, who was also deeply interested in Russia, to publish in 1912 an Adlerian study of Gogol-The Gogol Case - in a newly founded series. Otherwise, Adler's favorite author was Dostoevsky, and one wonders to what extent the Russian writer's criminal psychology may have influenced his own theory. In 1913 he urged Kaus, who by then was also on the staff of Psikhoterapiya, to write what he hoped would be a major study of Dostoevsky. The meetings of Adler's Society for Individual Psychology now very frequently addressed literary analyses regularly surveyed in Psikhoterapiya by Raisa Adler. 
This was the state of affairs when a Russian became Freud's most famous patient. In February 1910, Sergey Pankeev, eventually to be known as the "Wolfman," arrived from Odessa for a consultation. With him was Leonid Droznes, an Odessan psychiatrist who, as early as the summer of 1909, shortly after Dr. Vulf's article in Terapevticheskoe obozrenie, had attempted to treat Pankeev with psychoanalysis. As James Rice notes in Freud's Russia, he was "made to order" for Freud at this particular moment in 1910. Although he spoke almost fluent German, to Freud he exemplified a Russian national character with strong archaic vestiges that were manifested not least in a profound emotional ambivalence. These features seemed to enable Freud to penetrate deeper than anyone before him into the primitive strata of the personality and early childhood experiences to lay bare what he called the "primal trauma" (Urtrauma) of the afflicted psyche.

Freud had become interested in Russia early on, which perhaps had to do with the fact that he had grown up in a Slavic linguistic milieu in Moravia. He had been close friends with a couple of Russian fellow students when he studied with Jean Martin Charcot in Paris, and had co-authored a study on brain anatomy with one of them. His own mother had spent some important childhood years in Odessa, while one of his uncles had business ties to the city and had occasionally traveled there. The first foreign physician interested in psychoanalysis to come forward in Vienna was the Russian-born Max Eitingon, with whom Freud soon established a life-long friendship.

As Freud's analysis would conclude, Sergey Pankeev's father was the overshadowing Oedipal figure in his son's case history, an object of Sergey's "excessive love" and the source of his intense fear of castration. Freud briefly describes the father's life in his case study as "rich in events and experiences." Konstantin Pankeev was in fact one of the wealthiest men in southern Russia, a landowner, leftliberal politician, and patron of the arts. Freud's description, which was intentionally vague to avoid revealing the subject's identity, says nothing about the significant role he played in Russia early in the century. His social involvement was quite simply of no interest to an investigation of an "infantile neurosis," nor was the politically 
indifferent Freud capable of evaluating it. Freud mentions the adult Sergey's continued rivalry with his sister-his father's favorite and his "seductress" at an early age-but says not a word about his patient's jealousy of Pankeev Sr.'s political activities, which in fact seem to have had a bearing on the affliction he contracted in adolescence.

As Freud also notes, Konstantin Pankeev had been diagnosed as manic depressive. As in the case of Aleksey Venkstern, his illness seems to have fluctuated in close conformity with shifting political events in Russia. In his youth around 1880, he had gone "to the people" in the spirit of the age, an act that was all the more remarkable in that he was a millionaire. A few years after his son was born in 1886, he sank into depression, at the same time that political stagnation tightened its grip on Russia. In the years immediately preceding the 1905 Revolution he became almost maniacally active. In the summer of 1903 he participated in the historic meeting at Lake Constance (Bodensee), where liberals like himself and exMarxist intellectuals founded the so called Union of Liberation. He came incognito to avoid police surveillance, and arranged to issue advice and instructions for continued underground political activity in southern Russia. Beginning in the autumn of that year, he edited the Odessa journal Yuzhnye zapiski (Southern Notes), which he quickly attempted to make a center of political radicalism. In 1904, he donated a large sum of money (30,000 rubles) to "centralized terrorism," immediately after the reactionary Minister of the Interior Plehve was killed by a bomb in the middle of Petersburg. It was at this time that his son appears to have entered the apathetic state that would eventually bring him to Freud.

In the revolutionary autumn of 1905, the Pankeev home in Odessa seems to have become a debate club under the surveillance of the police, and a stream of brochures, proclamations, posters, and fliers issued from the offices of his periodical. Pankeev also helped found the Constitutional Democrat Party - the so called Kadets. He was elected to the Duma but withdrew to preserve his anonymity. His son reacted to all this by hobnobbing with young monarchists. Pankeev Sr. was dealt a heavy double blow in 1906, when the Revolution was crushed and his beloved daughter committed 


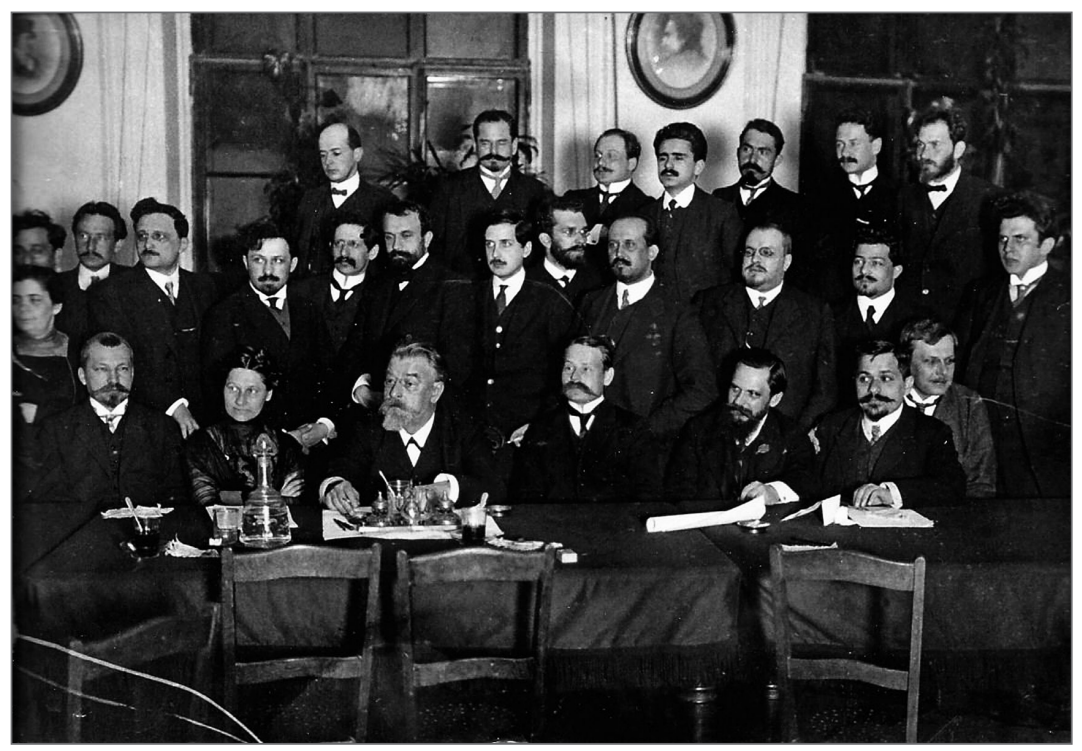

"Little Friday" meeting at the Moscow University $\rho_{\text {sychiatric }}$ Clinic in April 1911. In the middle row on the far right Nikolay Osipov, Mikhail Asatiani, and Osip Feltsman. Third from the left in the front row, dean of Russian psychiatry Vladimir Serbsky.

suicide. With his wife he began planning to make a large donation in her memory to a clinic in Odessa. He simultaneously initiated his most ambitious political and cultural undertaking, the Petersburg miscellany Zarnitsy (Summer Lightning), which was intended to illuminate the Russian gloom. His idea was to use his extensive network of contacts to gather the entire leftist intelligentsia (except the Bolsheviks) to embark upon a joint project. Writers, politicians, scholars, and journalists would be given an opportunity to describe and analyze the contemporary situation. Contributors included Ivan Bunin, Aleksandr Kuprin, and a number of prominent liberals. At this same time, Sergey slipped deeper and deeper into depression. By the time the first issue of Zarnitsy appeared in the spring of 1908, Konstantin Pankeev had already brought his son for hypnosis therapy to his friend Vladimir Bekhterev, the best known neurologist in Russia and one of the country's most prominent leftist personages. He put even more effort into the next volume, 
but in July 1908 he died suddenly of aortic stenosis at the age of fifty. The second and last issue of Zarnitsy, a volume of over 500 pages, appeared in early 1909. Thus it was only a short while later, when various treatments at German sanatoria had proved ineffective, that Droznes began experimenting with psychoanalysis on the apathetic Sergey.

It is not surprising that Sergey Pankeev should have immediately decided to stay with Freud. A year and a half after his father's death, he found in Freud an ideal paternal surrogate, a revolutionary of the psyche, an "explorer," as he himself called him, out to conquer a new world. And in this historic mission of his, Freud chose not to reject his "son." On the contrary, he took him into his confidence as a colleague and even focused his research on his own personality. Sergey, moreover, had grown up in a strongly Judeophile environment, for his father had been deeply involved in the Jewish question. Except for the war years, Sergey remained in Vienna the rest of his life, in contact throughout with psychoanalytic circles.

Thus, Sergey Pankeev had grown up in a genuinely literary environment and had personally met writers and journalists in his own home. It seems natural, therefore, that his memoirs should report that he and Freud often touched upon Russian literature in their conversations. Freud made clear that his fascination with Mikhail Lermontov, who was killed in a duel at an early age, was connected with his unexpressed grief over the death of his sister. They discussed in particular Dostoevsky, whom Freud evidently used extensively as a template in his approach to Pankeev and the Russian psyche. It seems significant that precisely in 1910, the first year of the analysis, Freud purchased not only Dostoevsky's complete works in 22 volumes, but also Dmitry Merezhkovsky's study Tolstoy and Dostoevsky. James Rice suggests that Dostoevsky's unique autobiographical story "The Peasant Marey" may have influenced Pankeev's treatment. That work describes Dostoevsky's fear of wolves as a child, and it seems to conform very well to Freud's interpretation of Dostoevsky in his later essay and of Pankeev as a latent homosexual in love with his paternal authorities, who alternately rebelled against and bowed down before the tsar and 
God. Freud considered The Brothers Karamazov the best novel ever written, and its role in the analysis had to do with the fact that Pankeev recognized Karamazovian features in his own family. Another topic of discussion was Merezhkovsky's novel Peter and Aleksey, which describes how Peter the Great had his son killed for opposing his reforms. The work was relevant to Pankeev's identification with the tsarevich, and it was also one of Freud's favorite novels. We can surmise that it was very easy for Pankeev to project his father's features onto the revolutionary Tsar Peter.

It is worth noting that as Freud was conducting his analysis of Pankeev, Bely was digging into the Russian trauma of parricide in Petersburg, taking both The Brothers Karamazov and Peter and Aleksey as equally central points of departure. Bely was not very familiar with Freud's theories, but they were in the air all around him. As we have seen, his friend Sergey Solovyov underwent psychoanalytical therapy with Kannabikh, and another friend, Emilii Medtner, soon consulted Freud directly.

Over the course of 1914, the philosopher Ivan Ilyin and Medtner went through analysis with Freud and Jung, respectively. Their therapies, which resulted directly from the breakthrough of psychoanalysis in Russia, deserve separate treatment. 